\title{
The effect of oil revenue funds on social welfare
}

Article

Accepted Version

Azhgaliyeva, D. (2018) The effect of oil revenue funds on social welfare. Public Finance Review, 46 (4). pp. 692-712. ISSN 1552-7530 doi:

https://doi.org/10.1177/1091142116681838 Available at https://centaur.reading.ac.uk/67645/

It is advisable to refer to the publisher's version if you intend to cite from the work. See Guidance on citing.

To link to this article DOI: http://dx.doi.org/10.1177/1091142116681838

Publisher: Sage

All outputs in CentAUR are protected by Intellectual Property Rights law, including copyright law. Copyright and IPR is retained by the creators or other copyright holders. Terms and conditions for use of this material are defined in the End User Agreement.

\section{www.reading.ac.uk/centaur}

\section{CentAUR}

Central Archive at the University of Reading

Reading's research outputs online 


\begin{abstract}
Recently it has become popular among oil-producing countries to establish oil revenue funds, which are believed to stabilize the economy and provide inter-generational redistribution. Oil revenue funds deffer depending on rules, such as accumulation rules and withdrawal rules. Numerical simulations show that funds can improve intergenerational social welfare, though not always. Which rule yields the highest intergenerational social welfare depends on countries' parameters such as gross interest rate, relative risk aversion and growth rate of oil production. Some rules may be unaffordable for a government budget. If oil production does not decline, funds following expenditure-based accumulation rules yield higher social welfare than funds that follow other rules. If oil production declines, the Permanent Oil Income model or "Bird-in-Hand" can yield the highest social welfare.
\end{abstract}

\title{
Keywords
}

sovereign wealth funds, fiscal rules, public finance, oil price 


\section{Introduction}

This paper investigates the effect of funds and their design on intergenerational social welfare. Fiscal policy is very challenging in oil-producing countries, where a large portion of revenue is generated from sales of oil. This is caused by two factors: 1) volatility and unpredictability of oil prices and 2) exhaustibility of oil reserves. The first factor causes difficulties in planning government expenditure, the adjustment of which is costly. Due to the second factor, it is important to save for future generations if society believes that oil wealth belongs not only to the current, but also to future generations of oil-producing countries. To limit the impact of revenue volatility and provide intergenerational distribution of oil wealth, many oil-producing countries have established oil revenue funds, while others are discussing the establishment of such funds and their design. Oil revenue funds are those sovereign wealth funds that are accumulated from oil-related revenue. These funds are funded by taxes paid by oil producers, fiscal surpluses, privatization of oil-related property and investment profits of the fund. The objectives of each country determine the optimal design of a fund: accumulation rules, withdraw rules, investments, etc.

The objective of this paper is to investigate the effect of oil revenue funds and their design on intergenerational social welfare. Engel and Valdés (2000) claim that a well-designed fund should be closely related to the solution of a problem and rules should be such that the fund implements the optimal fiscal strategy. Engel and Valdés (2000) study the problem of intergenerational distribution of oil.

Although many researchers have addressed the problem of the effect of the design of oil revenue funds on their performance, empirical results of existing literature are contradictory (Davis et al. 2003; Crain and Devlin 2003; Shabsigh and Ilahi 2007; Ossowski et al. 2008; Hart 2010). Empirical results have limitations when real data is used. The number of existing funds is not large and thus the number of funds' rules is also not large. The simulation of funds' rules allowes to consider a 
larger number of rules (some of them exist but most currently do not). Engel and Valdés (2000) introduce optimizing rules to maximize the social welfare function, considering the adjustment cost of government expenditure and the uncertainty of future oil prices. However, many countries set simple ad hoc rules for funds rather than optimizing rules. Maliszewski (2009) applied this idea in his paper by introducing a few ad hoc rules such as "Bird-in-Hand". His results show poor performance of ad hoc rules compared to optimizing rules. Some rules applied in oil-producing countries were also omitted in the above literature. The gap that we intend to fill in the existing literature is the consideration of different rules, some of which are used in oil-producing countries, and the consideration of the adjustment cost of government expenditure and the derivation of optimal government expenditure after oil is exhausted.

In this paper, we consider the optimizing rule (permanent oil income model), ad hoc rules (different combinations of accumulation rules and withdrawal rules of oil revenue funds) and no fund exists. By "no fund exists" it is meant that there are no ad hoc rules set and oil revenue is spent as it occures. We also consider the adjustment cost of government expenditure and uncertainty of oil prices. We simulated government expenditure paths when there is no fund and when different types of funds are established. Comparing intergenerational social welfare under different rules with the benchmark model (permanent oil income model), we can determine the rule for oil revenue funds that yields the highest social welfare in our sample. Ad hoc rules are based on a combination of accumulation and withdrawal rules. There are two types of accumulation rules: revenue-based and expenditure-based.

Countries with funds following an expenditure-based accumulation rule set a reference (budgeted) oil price that determines the government expenditure and the amount of oil income that accumulates the fund. For numerical simulations we set reference oil prices as moving averages (MAs) of past oil prices (as in Trinidad) and as fixed reference oil prices (as in Kazakhstan and 
Kuwait). Although many countries follow fixed reference oil prices, most of them adjust their reference oil prices according to their expectations of oil prices (for example, in Algeria, Kuwait, Nigeria and Mexico). So setting reference oil prices as moving averages is a realistic assumption. Withdrawals from a fund are allowed when the nominal oil price is lower than the reference oil price. The amount the government can withdraw equals the budget deficit. Countries with funds following revenue-based accumulation rules set a fixed portion of oil income that must be saved in the fund and the rest can be spent by the government. Withdrawals from such funds are not allowed (as in Canada), or are limited to interest earnings (as in Norway).

The rule that maximizes social welfare depends on the parameters of a country, such as gross interest rate, relative risk aversion and growth rate of oil production. There is no single rule or even type of rule that is suitable for all countries. The results show how each parameter affects the results. The results have implications for policymakers of oil-producing countries where an oil revenue fund exists or where the establishment of such a fund is under discussion. Apart of funds' rules policymakers need to concider governance of funds (Truman 2007). Even if fund follows optimal rule, oil revenue funds need good governance in order to work well (Palley 2003). Weak governance limits their performance (Kalyuzhnova 2006, 2011). Examples of weak governance are when rules are not followed or other ways are used to adjust constraint are discussed by Azhgaliyeva (2014). Appropriate rules do not guarantee success of oil revenue funds in the absance of good governance (Truman 2007).

\section{The Permanent Oil Income Model}

The permanent oil income model (POIM) "is that government net wealth - oil wealth plus net financial assets - is spent at a gradual pace that ensures a constant share for each generation according to some social welfare criteria" (Medas and Zakharova 2009: 22). The POIM assumes that oil wealth is equally distributed across all generations. 
The government provides the public good, $G_{t}$, which is financed by oil income, $Y_{t}^{\text {oil }}$. Non-oil income is assumed to be constant. However, it is possible that non-oil income positivelly depends on government expenditure due to positive external effects of government expenditure on consumption and productivity (Takizawa et al. 2004). For simplicity we assume no external effects of government expenditure on consumption and productivity. After period T, oil is exhausted. Oil income, $Y_{t}^{\text {oil }}$, is a government's income from sales of oil: $Y_{t}^{\text {oil }}=P_{t}^{\text {oil }} \times Q_{t}^{\text {oil }}$, where $Q_{t}^{\text {oil }}$ is a government's share of oil and $P_{t}^{\text {oil }}$ is oil price. Oil resources are owned by the government and extracted by oil producers. The government receives an oil production share (according to production sharing agreement) and then sells the oil. The fund earns interest from assets. We assume constant interest rate, $R$. We ignore the difference between the interest rate on debt and on foreign assets, so the government can borrow from international market at interest rate R. The government has initial financial assets $F_{0}$.

According to the POIM, the government keeps real per capita expenditure constant by transforming oil wealth into foreign assets, $F_{t}$, (oil revenue fund). The oil revenue fund accumulates a part of the oil revenue and invests them in foreign assets, which then could be withdrawn to cover a budget deficit.

The utility function of individual, $u_{t}$, only depends on consumption of public goods. Utility of individual is increasing with government expenditure per capita, $g_{t}$, and has decreasing marginal utility. The government chooses optimal expenditure by maximizing the social welfare function (SWF):

$$
\max _{g_{t}} W\left(u_{0}, u_{1}, \ldots\right)=\sum_{t=0}^{\infty} \beta^{t}(1+n)^{t} u_{t}=\sum_{t=0}^{\infty} \beta^{t}(1+n)^{t} \frac{g_{t}^{1-\rho}}{1-\rho}
$$

subject to dynamic budget constraint $F_{t+1}=R\left[F_{t}+Y_{t}^{\text {oil }}-G_{t}\right]$ and the government lifetime budget 
constraint (no Ponzi scheme) $\sum_{t=0}^{\infty} R^{-t} G_{t}=F_{0}+\sum_{t=0}^{T} R^{-t} Y_{t}^{\text {oil }}$, where $\rho$ is an intertemporal elasticity of substitution (coefficient of relative risk aversion), $\beta$ is a constant discount factor and $n$ is a growth rate of population.

Oil revenue is mostly uncertain due to unpredictability and volatility of oil prices. For this reason in this model we assume oil price uncertainty, while oil is extracted at a constant and predetermined rate. The government expenditure path is constructed sequentially, taking into account information that will be available at the time of decisions. The government uses the latest oil price to project future oil prices. Volatility of oil prices causes volatility of the optimal government expenditure path. Engel and Valdés (2000) provide the solution of POIM. Engel and Valdés (2000) proove that the optimal government expenditure is a function of the variance of initial income and the variance of oil price shock.

\section{After oil is exhausted}

After the oil is exhausted (at period $T+1$ ), there is no unpredictability of oil income: $Y_{t>T}=0$. Government expenditure is financed by withdrawals from the funds' assets. The government chooses the optimal government expenditure maximizing social welfare:

$$
\max _{g_{t}} W=\sum_{t=T+1}^{\infty} \beta^{t}(1+n)^{t} \frac{g_{t}^{1-\rho}}{1-\rho}
$$

subject to $F_{t+1}=R\left[F_{t}-G_{t}\right]$ and $\sum_{t=T}^{\infty} R^{-t} G_{t}=F_{T}$.

Using equations $g_{t}=G_{t} / N_{t}$ and $N_{t}=N_{0}(1+n)^{t}$, the solution yields the optimal government expenditure after oil is exhausted as follows:

$$
g_{t>T}=\frac{R-(\beta R)^{1 / \rho}(1+n)}{R} \frac{F_{t>T}}{N_{0}(1+n)^{t}} .
$$


The sum of social welfare functions before oil is exhausted (1) and after oil is exhausted (2) is as the following:

$$
W_{t=0}^{\infty}=\sum_{t=0}^{T} \beta^{t}(1+n)^{t} \frac{g_{t}^{1-\rho}}{1-\rho}+\frac{(\beta R)^{-(T+1)(1-\rho) / \rho}}{1-\beta(1+n)(\beta R)^{(1-\rho) / \rho}} \frac{g_{T+1}^{1-\rho}}{1-\rho} .
$$

\section{POIM with adjustment cost}

Optimal government expenditure per capita is not constant under oil income uncertainty. There is a negative effect of the government expenditure volatility on economic growth (Furceri 2007). Empirical evidence of the adjustment cost on government expenditure is also provided by Arpaia and Turrini (2008). Not only is a decrease in government expenditure costly, but also an increase. There is a limit to fully absorb increased government expenditure. Thus, we adopt quadratic adjustment cost from Engel and Valdés (2000). The optimal government expenditure is fixed after oil is exhausted from time $\mathrm{T}+1$ and, thus, there is only an adjustment cost until time $\mathrm{T}+1$. Thus, social welfare with the adjustment cost as follows:

$$
W_{t=0}^{\infty}=\sum_{t=0}^{T+1} \beta^{t}\left(\frac{g_{t}^{1-\rho}}{1-\rho}-k\left(\log \left(g_{t}\right)-\log \left(g_{t-1}\right)\right)^{2}\right)+\frac{(\beta R)^{-(T+2)(1-\rho) / \rho}}{1-\beta(1+n)(\beta R)^{(1-\rho) / \rho}} \frac{g_{T+2}^{1-\rho}}{1-\rho},
$$

where $\kappa$ is the weight of the adjustment cost.

\section{Oil Revenue Funds}

Many countries prefer to set simple ad hoc rules that determine the government expenditure. Unlike the POIM, the government does not need to determine the expenditure every year in this case. The government expenditure follows a simple formula according to accumulation and withdrawal rules. Accumulation rules split oil income between the government expenditure and the fund. There are two main types of accumulation rules: revenue-based (as a portion of oil revenue) and expenditurebased (as a budget surplus or as the revenue above the budgeted reference oil price). In this section, we assume that oil revenue is split between government expenditure and the fund according to 
revenue-based or expenditure-based accumulation rules. Funds that follow revenue-based rules are usually called saving funds. Funds that follow expenditure-based rules are usually called stabilization funds.

Withdrawal rules determine how much of the assets can be withdrawn from the fund to cover the budget deficit. The government can set constraints on withdrawals from the fund. If the government does not set constraints on withdrawals, then any budget deficit can be covered by the fund. If the government sets constraints on withdrawals, then only a certain part of the fund's assets can be withdrawn per year or no withdrawals are allowed. In this section, the three cases are considered : 1) no constraints on withdrawals from the fund, 2) withdrawals from the fund are limited to interest earnings, and 3) no withdrawals allowed. Stabilization funds usually have no constraints on withdrawals. Saving funds usually have constraints on withdrawals, which are usually either not allowed or limited to interest earnings.

A combination of accumulation and withdrawal rules define the pattern of the government expenditure over time. In this paper, combinations of accumulation and withdrawal rules that are commonly used by oil-producing countries are considered.

\section{Saving funds}

Saving funds follow the revenue-based accumulation rule. Under this rule, oil revenue is split by a fixed proportion between the government expenditure and the fund. Assume that after the oil is exhausted, the government can only spend assets according to equation (3). This ensures that the fund's assets are never exhausted and left for future generations.

The government expenditure is constrained as follows: $G_{t \leq T}=\varphi_{t} Y_{t}^{\text {oil }}$, where $1-\varphi$ is a share of oil revenue that accumulates the fund and $0 \leq \varphi \leq 1$. If $\varphi=1$, there is no fund, and if $\varphi=0$, all oil revenue is accumulated in the fund. Thus the government expenditure per capita as follows: 
$g_{t \leq T}=\varphi_{t} y_{t}^{\text {oil }}$, where $y_{t}^{\text {oil }}$ is oil income per capita $\left(y_{t}^{\text {oil }}=Y_{t}^{\text {oil }} / N_{t}\right)$. The government chooses the optimal share of oil revenue that must be saved in the fund, thereby maximizing the social welfare:

$$
\max _{1-\varphi_{t}} W=\sum_{t=0}^{\infty} \beta^{t}(1+n)^{t} \frac{\left(\varphi_{t} y_{t}^{o i l}\right)^{1-\rho}}{1-\rho}
$$

subject to dynamic budget constraint $F_{t+1}=R\left[F_{t}+\left(1-\varphi_{t}\right) Y_{t}^{\text {oil }}\right]$ and the government lifetime budget constraint $\sum_{t=0}^{\infty} R^{-t} \varphi_{t} Y_{t}^{o i l}=F_{0}+\sum_{t=0}^{T} R^{-t} Y_{t}^{o i l}$. Proceeding the same way as in the POIM, the above equations yield the following solution:

$$
\varphi_{t} y_{t}^{o i l}=(\beta R)^{1 / \rho} \varphi_{t-1} y_{t-1}^{o i l}
$$

The optimal initial share of oil revenue that accumulates the fund as following:

$$
1-\varphi_{0}=1-\left(1-\frac{(1+n)(\beta R)^{1 / \rho}}{R}\right) \frac{F_{0}+\sum_{t=0}^{T} R^{-t} Y_{t}^{\text {oil }}}{Y_{0}^{\text {oil }}}
$$

Optimal $\varphi_{t}$ is not constant under oil income uncertainty. Ad hoc rules assume that the rule is set once and does not require adjustment every year: $\varphi_{t}=\varphi$. There is no simple solution for the optimal accumulation rule when oil income is uncertain. This solution requires numerical simulations.

\section{"Bird-in-Hand"}

The "Bird-in-Hand" $(\mathrm{BIH})$ rule is a specific combination of accumulation and withdrawal rules. A fund following $\mathrm{BIH}$ rule accumulates 100 percent of the oil revenue, while withdrawals from the fund are constrained to interest earnings on financial assets (Harding and Van der Ploeg 2009). An example of such fund is the government pension fund in Norway. This fund allows for saving more in early years so that the government can afford higher spending in later years (by future generations). This fund reduces volatility of government expenditure, but returns on the assets could increase volatility since the interest earnings of financial assets can be withdrawn and spent 
by the government.

The government expenditure is constrained by: $G_{t}=(R-1) F_{t}$. Thus the government expenditure

per capita as follows: $g_{t}=(R-1) \frac{F_{t}}{N_{0}(1+n)^{t}}$.

\section{Stabilization funds}

A stabilization fund's accumulation rule is based on a reference oil price, or on a budget surplus.

Both cases are identical. Under this rule, the budget surplus, which is actual oil revenue less budgeted expenditure, accumulates the fund. Budgeted expenditure is based on the budgeted oil price, which is called the reference oil price. If the budget has a deficit, financial assets can be withdrawn from the fund to cover the budget deficit. We assume no constraints on withdrawal rules.

The expenditure-based accumulation rule sets constraints on the government expenditure: $G_{t \leq T}=P_{t}^{r e f} Q_{t}^{\text {oil }}$, where $P_{t}^{r e f}$ is a reference oil price, which is set by the government and $Q_{t}^{\text {oil }}$ is oil production. Thus the government expenditure per capita as follows: $g_{t \leq T}=P_{t}^{\text {ref }} q_{t}^{\text {oil }}$, where $q_{t}^{\text {oil }}$ is oil production per capita $\left(q_{t}^{\text {oil }}=Q_{t}^{\text {oil }} / N_{t}\right)$. If $P_{t}^{\text {oil }}>P_{t}^{\text {ref }}$, then a part of the oil revenue (budget surplus) is transferred to the fund, and if $P_{t}^{o i l}<P_{t}^{r e f}$, then a part of the assets is withdrawn from the fund to cover the budget deficit.

With the stabilization fund, the government chooses the optimal reference oil price maximizing social welfare:

$$
\max _{P_{t}^{r e f}} W=\sum_{t=0}^{\infty} \beta^{t}(1+n)^{t} \frac{\left(P_{t}^{r e f} q_{t}^{\text {oil }}\right)^{1-\rho}}{1-\rho}
$$

subject to dynamic budget constraint $F_{t+1}=R\left[F_{t}+\left(P_{t}^{\text {oil }}-P_{t}^{r e f}\right) Q_{t}^{\text {oil }}\right]$ and government lifetime 
budget constraint $\sum_{t=0}^{\infty} R^{-t} P_{t}^{r e f} Q_{t}^{\text {oil }}=F_{0}+\sum_{t=0}^{T} R^{-t} Y_{t}^{\text {oil }}$.

Proceeding the same way as in section 2, the solution of the above equations yields:

$$
P_{t}^{r e f} q_{t}^{o i l}=(\beta R)^{1 / \rho} P_{t-1}^{r e f} q_{t-1}^{o i l}
$$

Thus, the optimal reference oil price is as follows:

$$
P_{0}^{r e f}=\left(1-\frac{(1+n)(\beta R)^{1 / \rho}}{R}\right) \frac{F_{0}+\sum_{t=0}^{T} R^{-t} Y_{t}^{\text {oil }}}{Q_{0}^{\text {oil }}}
$$

There is no simple solution for the optimal reference oil price under oil income uncertainty, which is why we need to apply numerical simulations. The government can set a fixed reference oil price, $P_{t}^{r e f}=P^{r e f}$, or the government can set it as a moving average of past oil prices:

$$
P_{t}^{r e f}=\frac{1}{M} \sum_{j=1}^{M} P_{t-j}
$$

where $M$ denotes a number of years.

\section{Numerical Comparisons}

\section{Monte Carlo simulation of oil prices}

A quantitative comparison of the rules are performed through Monte Carlo (MC) simulations (Metropolis and Ulam 1949) of oil prices. MC simulation is a numerical method that is used when no closed-form solution is available. It is a random number generator that simulates stochastic processes such as oil prices. In order to run MC simulation, we need to determine parameters and distribution of past data. In order to find parameters, the following data was used: annual world oil prices in US Dollars per barrel over the period 1952-2011 (International Monetary Fund 2011). Real oil prices were obtained by deflating nominal oil prices using the consumer price index of the United States of America (International Monetary Fund 2011) in 2000. 
Assume that oil prices follow the process:

$$
\log \left(p_{t}\right)=\alpha+\Psi \log \left(p_{t-1}\right)+v_{t}
$$

where $v_{t}$ is a normally distributed shock with variance $\sigma_{v}^{2}$. Let oil price at $t=0$ be $p_{0}$, with mean $\mu_{p, 0}$ and variance $\sigma_{p, 0}^{2}$. Thus, initial oil income, $Y_{0}^{\text {oil }}$, has mean $\mu_{0}=\mu_{p, 0} Q_{0}$ and variance $\sigma_{0}^{2}=\sigma_{p, 0}^{2} Q_{0}^{2}$. There is uncertainty about parameters of the oil price process in the existing literature. In this paper, the simple regression (equation 8) suggested by Engel and Valdés (2000) was used. The empirical literature about stationarity of oil prices provide contradictory results. The results depend on the sample size, period of data and unit root tests. Taking into account the ambiguity of the problem to determine stationarity of the oil price process, we adopted the solution proposed by Maliszewski (2009). We assumed a near unit root process setting the coefficient $\Psi$ (in equation 8) at 0.99 .

The Monte Carlo simulation for oil prices with 5,000 repetitions over a 200-year horizon was performed. Real oil prices and simulated are shown in Figure 1 The simulated oil prices were then used to derive the paths for per capita government expenditure under different rules.

\section{Initial conditions and parameters}

Parameters and initial conditions for simulation exercises were used from Table 1. To compare social welfare with different types of funds, two types of accumulation rules were considered: revenue-based and expenditure-based. To compare funds following revenue-based accumulation rules, different parameters of share of oil revenue that accumulates a fund, $\varphi$, were considered in the simulation exercises: $10,15,25,30,50,75$ and 100 percent $(\mathrm{BIH})$. To compare the funds that follow expenditure-based rules, different parameters of reference oil price, $p^{\text {ref }}$, were considered in the simulation exercises: between 9 and 40 US dollars per barrel. Only whole numbers were considered as reference oil prices. Countries set reference oil prices only as whole numbers (Table 
2). Also the reference oil prices following moving averages of past oil prices were considered: 3 , 5, 7 years (as Bartsch 2006); 10 years (as in Mexico); and 11 years (as in Trinidad). The reason for that is that some countries adjusted their reference oil prices to nominal oil price fluctuations. The summary of rules is in Table 3.

Results

Some rules were omitted because they lead to permanent budget deficit. It is important to analyze the affordability of rules under different parameters. Unaffordable rules are rules that lead to permanent budget deficit. Accumulation rules based on reference oil prices can be unaffordable. Rules based on revenue are always affordable. Rules based on too high reference oil prices, i.e. above 27 US dollars per barrel, yield unsustainable budget deficit. The results show that the existence of a fund does not guarantee an improvement in social welfare. Some funds can lead to lower social welfare than when no fund exists. The comparison of the POIM with ad hoc rules shows that the POIM is not always better than ad hoc rules. Likewise, after comparing types of accumulation rules, we cannot say that expenditure-based rules are better than revenue-based, or vice versa. However most expenditure-based rules perform better than revenue-based rules. Expenditure-based rules with an overly low reference oil price (9, 10 and 11 US dollars per barrel) perform worse than other expenditure based rules. From the results, it appears that rules based on lower percentages of oil revenue that accumulate the fund lead to higher social welfare. The rule based on zero percent which accumulates the fund (no fund exists) leads to the highest social welfare compared to other revenue based rules. The rule that yields the highest social welfare in our sample is when the fund exists and follows the expenditure-based accumulation rule with the fixed reference oil price at 25 US dollars per barrel.

One of the objectives of funds is to save oil revenue for future generations. Under different rules, different amounts of financial assets are saved depending on the period of time. In this paper we 
analyze only the amount of financial assets saved for future generations after the oil is exhausted. The existence of a fund does not guarantee that more financial assets will be saved for future generations. Some expenditure-based accumulation rules save less than if no fund exists. All expenditure-based accumulation rules with reference oil prices based on a moving average in our sample save less than if no fund exists. The rule with the highest sustainable fixed reference oil price, 27 US dollars per barrel, saves the least financial assets for future generations. All revenuebased accumulation rules save more than if no fund exists. Indeed, only revenue-based rules appear to guarantee savings for future generations. The higher the percentage that accumulates the fund, the higher the savings in the fund. The lower the fixed reference oil price, the more financial assets are saved for future generations.

\section{Analysis with different initial parameters}

Results depend on initial parameters (Maliszewski 2009). To determine how results are affected by chosen parameters, we analyze social welfare under different parameters: gross interest rate, relative risk aversion and oil production growth rate (Table 4).

Firstly, we consider different gross interest rates. Oil revenue funds in different countries invest in assets with different interest rates and riskiness. Gross interest rate affects affordability of rules. Rules based on reference oil prices can be not affordable depending on interest rates. The higher the interest rate on assets, the higher reference oil price is affordable. The reference oil price determines how much of oil revenue can be spent. Higher interest rates mean greater savings in funds, meaning less oil revenue is needed to be accumulated in funds. Thus, a greater reference oil price is affordable. When interest rates range from one to ten percent, rules that yield the highest social welfare are based on fixed reference oil prices. As the interest rate increases, the higher reference oil price yields the highest social welfare. A higher interest rate on foreign assets means higher savings for future generations and thus it is less needed to be saved and more can be spent 
before the oil is exhausted, which assumes a higher reference oil price. The second- and third-best rules that yield highest social welfare are based on either fixed reference oil prices, or reference oil prices based on moving averages of past oil prices. At lower interest rates (from one to five percent), rules based on fixed reference oil prices are in the top three rules. At higher interest rates (from six to ten percent), reference oil prices based on a moving averages of oil prices appear in the second- or third-best rules in terms of yielding the highest social welfare. So, when the interest rate on assets is high enough, a reference oil price based on a moving average could be the secondbest option to increase social welfare.

Secondly, we consider how relative risk aversion affects social welfare under different rules. In the previous section, relative risk aversion equals three $(\rho=3)$ was assumed (as in Engel and Valdés 2000; Maliszewski 2009); however, some literature suggest relative risk aversion equals two (Arrau and Claessens 1992; Bartsch 2006) or four (Barro 2009). The reference oil price of 25 US dollars per barrel yields the highest social welfare under relative risk aversions two, three, and four. Rating of the rest of rules varies with different coefficients of relative risk aversion.

Lastly, we consider how the growth rate of oil production affects social welfare under different rules. In the previous section, an oil production rate of zero was assumed; however, the data of average growth rate of oil production in major oil-producing countries for the 10 -year period (2002 - 2011) varies by country from -6 to 19 percent (Table 5). We analyze not only positive growth rates of oil production but also negative. In many countries there are negative growth rates of oil production (for example, in Libya, UK and Norway). This means that oil is depleting in those countries. The oil production growth rate affects oil revenue and thus government expenditure and financial assets. The growth rate of oil production affects the affordability of rules. The higher the growth rate of oil production, the lower reference oil price is affordable. With any of the growth 
rates of oil production we considered, the best three accumulation rules are based on fixed reference oil prices. For growth rates of oil production from 0 to 7 percent, the highest social welfare is generated under the rule based on the reference oil price of 25 US dollars per barrel. With a growth rate of oil production from 8 to 9 percent, the rule that is affordable and yields the highest social welfare is based on the reference oil price of 24 US dollars per barrel. At a 19 percent growth rate of oil production, the rule that yields the highest social welfare is based on the reference oil price of 22 US dollars per barrel. The lower oil production growth rate, the higher reference oil price yields the highest social welfare, which means less oil revenue needs to be saved in a fund and more can be spent. When oil production falls at lower rates (one, two and three percent), rules that yield the highest social welfare are based on fixed reference oil prices. When oil production falls at greater rate, rules, that yield the highest social welfare, are the POIM (at four and five percent) and the $\mathrm{BIH}$ rule (from six to ten percent). The $\mathrm{BIH}$ and the POIM rules become more attractive when oil production decreases at a greater rate.

\section{Discussions and Conclusions}

We found that the existence of a fund does not guarantee an improvement in social welfare and determined the rule that yields the highest social welfare in our sample. In most cases under different parameters, rules that yield the highest social welfare are expenditure-based (fixed reference oil price or reference oil price following a moving average of oil prices). This is becaues expenditure-based rules stabilize government expenditure, and thus, maximize social welfare if $\beta R=1$ (Engel and Valdés 2000). Only when oil production declines at a rate high enough (between -4 and -10 percent) do the POIM and the BIH yield the highest social welfare than expenditure-based rules.

It is clear that funds that follow revenue-based rules guarantee savings for future generations. Nevertheless, the results show that larger savings for future generations do not imply greater social 
welfare. This result is consistent with Landon and Smith (2013). Not all rules are affordable. Some rules can lead to a permanent budget deficit. The results show that expenditure-based rules can be unaffordable. An interesting result is that not only can fixed reference oil prices be unaffordable, but so can reference oil prices based on moving averages of oil prices. The POIM can be unaffordable when oil production declines at a rate high enough (7-10 percent). However if nonoil income is increasing with government expenditure (Takizawa et al. 2004), more rules will be affordable, as budget could rely more on non-oil income and become less dependent on oil-income as government spends more. Changes in parameters such as growth rate of oil production and gross interest rate also affect the affordability of rules.

The analysis above shows that there exists a tradeoff between expenditure-based and revenue-based rules (Table 6). Our results contradict Maliszewski's (2009), which show poor performance of ad hoc rules. This could be due to the limited number of ad hoc rules considered by Maliszewski (2009). We started by looking for a rule that yields the highest social welfare, but then we found that there are several parameters that affect results. We showed how parameters of a country affect the performance of rules. Most parameters that were considered in this paper can vary and can be uncertain in the real world, so it is important to consider different parameters.

Since oil prices are uncertain, we used a numerical simulation of future oil prices based on past oil prices. The parameters could be different depending on the estimation model of oil prices. Existing literature do not agree on the model that should be used for estimation of oil price. Moreover a fixed interest rate on foreign assets is assumed in this paper. However, in the real world it varies and, in most cases, is uncertain. The same interest rate on debt and financial assets is assumed in this paper. However, in the real world they are more likely to be unequal. Also only a limited number of rules were considered in this paper, primarily accumulation rules. Other withdrawal rules and their combinations with accumulation rules could be considered in future research. Some 
countries, such as Kuwait, Oman, Saudi Arabia and UAE, have more than one fund for different purposes with different accumulation and withdrawal rules. Combinations of different funds could also be considered in future research.

In this paper we concentrated on long-term performance (intergenerational social welfare). Government expenditure paths were simulated under different rules. The optimizing rule (POIM) and ad hoc rules were considered. The numerical simulations show that there is no single rule optimal for all countries. The performance of different rules of funds depends on parameters such as growth rate of oil production, relative risk aversion and gross interest rate. This paper provides a framework for the comparison of different types of funds. This method can be used to simulate performance of funds under different initial conditions and parameters for different countries. We believe that our results may improve knowledge about the design of oil revenue funds. Our research could be a useful aid to decision makers in countries where such funds exist, or their establishment and design are under debate. The results of this paper provide practical implications for policy makers in oil-producing countries.

In oil-producing countries, the existence of a fund does not guarantee improvement in social welfare. The design of funds is crucial; appropriate rules can increase social welfare. Higher financial assets saved in funds do not imply higher social welfare. In countries where the adjustment cost on government expenditure is high enough, expenditure-based rules with fixed reference oil price or reference oil price following the moving average of oil prices are more suitable than revenue-based rules. In countries where oil production declines at a rate great enough, the POIM or BIH can improve social welfare. Otherwise, expenditure-based rules (with fixed reference oil price or reference oil price following moving average) yield the highest social welfare. In countries where funds follow expenditure-based rules, the choice of reference oil price must be made with care. Some reference oil prices can be unaffordable, leading to a permanent budget 
deficit. Both fixed reference oil prices and those following a moving average of oil prices can be unaffordable. There is no clear answer as to which reference oil prices are not affordable. The answer depends on gross interest rate and oil production growth rate. A budget deficit can be avoided if a fund follows a revenue-based rule because only revenue-based rule is always affordable.

An investment policy in assets needs to be considered in the design of a fund, or at least taken into consideration. Interest rates on returns from foreign assets affect affordability and the rating of rules. After oil is exhausted, when there is no uncertainty from oil prices, the optimal government expenditure maximizing social welfare is as in equation (3).

In summary, the results in this paper suggest that funds should be designed with caution in oilproducing countries, with consideration given to parameters such as gross interest rate, relative risk aversion and oil production growth rate. These findings add to a growing body of literature on the understanding of oil revenue funds. 


\section{Declaration of Conflicting Interests}

The author(s) declared no potential conflicts of interest with respect to the research, authorship, and/or publication of this article.

\section{Funding}

The author(s) received no financial support for the research, authorship, and/or publication of this article. 


\section{References}

Arpaia, Alfonso, and Alessandro Turrini. 2008. Government expenditure and economic growth in the EU: long-run tendencies and short-term adjustment. European Commission DirectorateGeneral for Economic and Financial Affairs Economic Papers 300:1-45.

Arrau, Patricio, and Stijn Claessens. 1992. Commodity stabilization funds. The World Bank Policy Research Working Paper Series 835.

Azhgaliyeva, Dina. 2014. The effect of fiscal policy on oil revenue fund: The case of Kazakhstan. Journal of Eurasian Studies 5(2): 157-183.

Barro, Robert J. 2009. Rare disasters, asset prices, and welfare costs. The American Economic Review 99: 243-264.

Bartsch, Ulrich. 2006. How much is enough? Monte Carlo simulations of an oil stabilization fund for Nigeria. International Monetary Fund Working Paper 06/142.

Crain, Mark, and Julia Devlin. 2001. Non-renewable resource funds: A red herring for fiscal stability? In Proceedings of the American Political Science Association Meeting, Washington, D.C.

Davis, Jeffrey M., Rolando Ossowski, James A. Daniel, and Steven Barnett. 2003. Stabilization and Savings Funds for Nonrenewable Resources and Fiscal Policy Implications. In Fiscal Policy Formulation and Implementation in Oil-Producing Countries, Jeffrey M. Davis, Annalisa Fedelino, Rolando Ossowski, ed., 273-315. International Monetary Fund, Washington D.C.

Engel, Eduardo and Rodrigo Valdés. 2000. Optimal fiscal strategy for oil exporting countries. International Monetary Fund Working Paper 00/118.

International Monetary Fund. 2012. International Financial Statistics, ESDS international, University of Manchester, http://dx.doi.org/10.5257/imf/ifs/2012-12.

Furceri, Davide. 2007. Is government expenditure volatility harmful for growth? A cross-country analysis. Fiscal Studies 28(1):103-120. 
Harding, Torfinn, and Rick Van der Ploeg. 2009. Is Norway's Bird-in-Hand stabilization fund prudent enough? Fiscal reactions to hydrocarbon windfalls and graying populations. CESifo Working Paper Series 2830.

Hart, Jason. 2010. Revenue funds counteract the determinants of Dutch disease: Lessons for Western Australia. In Proceedings of the Australian Agricultural and Resource Economics Society $54^{\text {th }}$ Annual Conference.

Kalyuzhnova, Yelena. 2006. Overcoming the curse of hydrocarbon: goals and governance in the oil funds of Kazakhstan and Azerbaijan. Comparative Economic Studies 48 (4): 583-613.

Kalyuzhnova, Yelena. 2011. The National Fund of the Republic of Kazakhstan (NFRK): From accumulation to stress-test to global future. Energy policy 39 (10): 6650-6657.

Kirabayeva, Koralai, Francisco Parodi and Yahia Said. 2013. Iraq: Selected Issues. International Monetary Fund Country Report 13/218, Washington, D.C.

Landon, Stuart, and Constance Smith. 2013. Government Revenue Stabilization Funds: Do They Make Us Better Off?. Canadian Public Policy 39 (1): 71-99.

Maliszewski, Wojciech. 2009. Fiscal policy rules for oil-producing countries: A welfare-based assessment. International Monetary Fund Working Paper 09/126.

Paulo A. Medas and Daria Zakharova. 2009. A primer on fiscal analysis in oil-producing countries. International Monetary Fund Working Paper 09/56.

Metropolis, Nicholas, and Stanislaw Ulam. 1949. The Monte Carlo method. Journal of the American Statistical Association 44 (247): 335-341.

Ossowski, Rolando, Mauricio Villafuerte, Paulo A. Medas and Theo Thomas. 2008. Managing the oil revenue boom: The role of fiscal institutions. International Monetary Fund Occasional Paper 260.

Palley, Thomas I. 2003. Lifting the natural resource curse. Foreign Service Journal 80 (12): 54- 
61.

Shabsigh, Ghiath, and Nadeem Ilahi. 2007. Looking beyond the fiscal: Do oil funds bring macroeconomic stability? International Monetary Fund Working Papers 07/96:1-18.

Takizawa, Hajime, Edward Gardner and Kenichi Ueda. 2004. Are Developing Countries Better Off Spending Their Oil Wealth Upfront? International Monetary Fund Working Paper 04/141.

Truman, Edwin. 2007. Sovereign wealth fund acquisitions and other foreign government investments in the United States: Assessing the economic and national security implications. Testimony before the Committee on Banking, Housing, and Urban Affairs, United States Senate, 14. 
Table 1. Initial conditions and parameters

\begin{tabular}{lcc}
\hline \multicolumn{1}{c}{ Parameters } & Notation & Value \\
\hline Discount factor & $\beta$ & $1 / \mathrm{R}$ \\
Population & $\mathrm{N}$ & 1 \\
Relative risk aversion & $\rho$ & 3 \\
Oil production & $\mathrm{Q}$ & 100 \\
Oil extraction rate & $\mathrm{g}$ & 0 \\
Population growth rate & $\mathrm{n}$ & 0 \\
Interest rate & $\mathrm{R}$ & 1.05 \\
Initial financial assets & $F_{0}$ & $\mu_{p} Q$ \\
Mean of real oil prices & $\mu_{p}$ & 28 \\
Standard deviation of real oil prices & $\sigma_{p}$ & 19.9 \\
Standard deviation & $\sigma_{v}$ & 0.25 \\
Adjustment cost & $s_{n a}$ & 0.20 \\
Adjustment cost & $s_{a}$ & 0.10 \\
\hline
\end{tabular}


Table 2. Accumulation rules by countries

\begin{tabular}{|c|c|c|}
\hline Country & $\begin{array}{c}\text { Reference oil price (USD/barrel)/percent of } \\
\text { oil revenues }\end{array}$ & Source \\
\hline Algeria & \$19 (2000), \$22 (2006), \$37 (2009) & www.swfinstitute.org \\
\hline Azerbaijan & $\begin{array}{l}\text { Expenditure-based (withdrawals are allowed } \\
\text { to finance important nation-wide projects) }\end{array}$ & Presidential Degree N579/2001 \\
\hline Canada & $30 \%$ (1976- 1983), 15\% (1984-1987) & www.finance.alberta.ca \\
\hline Iran & $20 \%$ with $3 \%$ increase annually & en.ndfi.ir \\
\hline Kazakhstan & $\begin{array}{l}\$ 19 \text { (2001-2005), withdraw limit of } 1 / 3 \text { size of } \\
\text { the fund (2006-2009), fixed amount withdraw } \\
\text { of } \$ 8 \text { bn. (plus/minus } 15 \% \text { ) per year and save } \\
20 \% \text { of the forecast GDP (from } 2010 \text { ) }\end{array}$ & $\begin{array}{l}\text { Presidential Decree } \\
\text { N543/2001, N1641/2005, } \\
\text { N962/2010, Azhgaliyeva } \\
\text { (2014), Kalyuzhnova (2006 \& } \\
\text { 2011) }\end{array}$ \\
\hline Kuwait & $\begin{array}{l}\text { Revenue-based } 10 \% \text { and reference price is set } \\
\text { in budget annually }\end{array}$ & www.kia.gov.kw \\
\hline Nigeria & $\begin{array}{l}\text { Reference price is set in budget annually ( } \$ 75 \\
\text { in 2011) }\end{array}$ & $\begin{array}{l}\text { www.budgetoffice.gov.ng } \\
\text { (Budget Implementation } \\
\text { Report) }\end{array}$ \\
\hline Norway & $\begin{array}{l}100 \% \text { and withdrawals of expected real } \\
\text { returns }(4 \%)\end{array}$ & www.nbim.no \\
\hline Oman & $\begin{array}{l}\text { Reference price is set in budget annually ( } \$ 85 \\
\text { in 2014) }\end{array}$ & $\begin{array}{l}\text { www.cbo-oman.org (Annual } \\
\text { report) }\end{array}$ \\
\hline Qatar & $\begin{array}{l}\text { Reference price set in budget annually ( } \$ 65 \text { in } \\
2014 \text { ) }\end{array}$ & $\begin{array}{l}\text { www.qatarinvestmentfund.com } \\
\text { (Annual report) }\end{array}$ \\
\hline Russia & $\begin{array}{l}\$ 20(2004-2005), \$ 27(2006-2008), \$ 45 \\
(2008-2010), 5 \text {-years MA (+1 year annually } \\
\text { from } 2013 \text { till 10-years MA), maximum } \\
\text { reserves in Reserve fund } 10 \% \text { of GDP } \\
(2008-2010) \text { and } 7 \% \text { of GDP (from } 2011)\end{array}$ & $\begin{array}{l}\text { www.budget.gov.ru (Budget } \\
\text { Code ch.13.2) }\end{array}$ \\
\hline Trinidad & $\begin{array}{l}11 \text {-year MA ( } 5 \text { past, current and } 5 \text { future } \\
\text { years) }\end{array}$ & Kirabaeva et al. (2013) \\
\hline Venezuela & \$17 (1998), \$9 (1999-2000) & Davis et al. (2003) \\
\hline Mexico & $\begin{array}{l}\$ 1.5(2000-2005), \text { weight of } 3 / 4 \text { to oil futures } \\
\text { prices and } 1 / 4 \text { to } 10 \text { years MA }(2006-2010)\end{array}$ & swfinstitute.org \\
\hline USA & $25 \%$ (1976-1979), 50\% (1980-2010) & www.apfc.org \\
\hline
\end{tabular}


Table 3. Summary of rules

\begin{tabular}{lll}
\hline \multicolumn{1}{c}{ Rule } & \multicolumn{1}{c}{ Accumulation } & \multicolumn{1}{c}{ Withdrawal } \\
\hline Expenditure-based & Revenue above reference price & No \\
Revenue-based & Percentage of oil revenue & No \\
BIH & $100 \%$ of oil revenue & Interest earnings \\
POIM & Above optimal government expenditure & No \\
\hline
\end{tabular}


Table 4. Rating of rules under different growth rates of oil production

\begin{tabular}{cccc}
\hline $\begin{array}{c}\text { Parameters } \\
\text { Interest rate }\end{array}$ & $\begin{array}{c}\text { 1st best, reference price } \\
\text { (USD/barrel) }\end{array}$ & $\begin{array}{c}\text { 2nd best, reference price } \\
\text { (USD/barrel) }\end{array}$ & $\begin{array}{c}\text { 3rd best, reference price } \\
\text { (USD/barrel) }\end{array}$ \\
$1 \%$ & 11 & 10 & 9 \\
$2 \%$ & 17 & 19 & 15 \\
$3 \%$ & 22 & 20 & 19 \\
$4 \%$ & 24 & 23 & 22 \\
$5 \%$ & 25 & 24 & 26 \\
$6 \%$ & 26 & 11 -year MA & 25 \\
$7 \%$ & 27 & 11 -year MA & 10 -year MA \\
Relative risk aversion & & & \\
2 & 25 & 26 & 24 \\
3 & 25 & 24 & 26 \\
4 & 25 & 24 & 26 \\
Oil production growth & & & 23 \\
$0-2 \%$ & 25 & 24 & 23 \\
$3-7 \%$ & 25 & 24 & 22 \\
$8 \%$ & 24 & 25 & 19 \\
$9 \%$ & 24 & 23 & 24 \\
$19 \%$ & 22 & 20 & 24 \\
$-1 \%$ & 25 & 26 & 25 \\
$-2 \%$ & 26 & 25 & 25 \\
$-3 \%$ & 26 & POIM & 27 \\
$-4 \%$ & POIM & 26 & \\
$-5 \%$ & POIM & 26 & 27 \\
$-6--7 \%$ & BIH & 28 & \\
$-8,-9$ and & BIH & & \\
$10 \%$ & & & \\
\hline
\end{tabular}


Table 5. Average growth rates of oil production (2002-2011)

\begin{tabular}{lc}
\hline \multicolumn{1}{c}{ Country } & Growth rate of oil production, \% \\
\hline Libya & -6 \\
UK and Syria & -5 \\
Norway and Australia & -4 \\
Indonesia & -3 \\
Mexico & -2 \\
Argentina, Malaysia and Venezuela & -1 \\
Oman, Egypt and Algeria & 0 \\
USA and Iran & 1 \\
India, Iraq and China & 2 \\
Canada, Ecuador, Saudi Arabia, Nigeria and UAE & 3 \\
Russia & 4 \\
Kuwait, Qatar and Brazil & 5 \\
Colombia & 6 \\
Kazakhstan & 7 \\
Angola & 9 \\
Azerbaijan & 19 \\
\hline
\end{tabular}

Sources: International Energy Agency (2012): Oil Information (Edition: 2012);

Table 6. Comparison of revenue-based and expenditure-based rules

\begin{tabular}{lll}
\hline \multicolumn{1}{c}{ Objectives } & \multicolumn{1}{c}{ Revenue-based rule } & \multicolumn{1}{c}{ Expenditure-based rule } \\
\hline Social welfare & Lower in most cases & Higher in most cases \\
Affordability & Always & Not always \\
Savings for future & Guaranteed & Not guaranteed \\
generations & & \\
Adjustment cost & More affected & Less affected \\
\hline
\end{tabular}




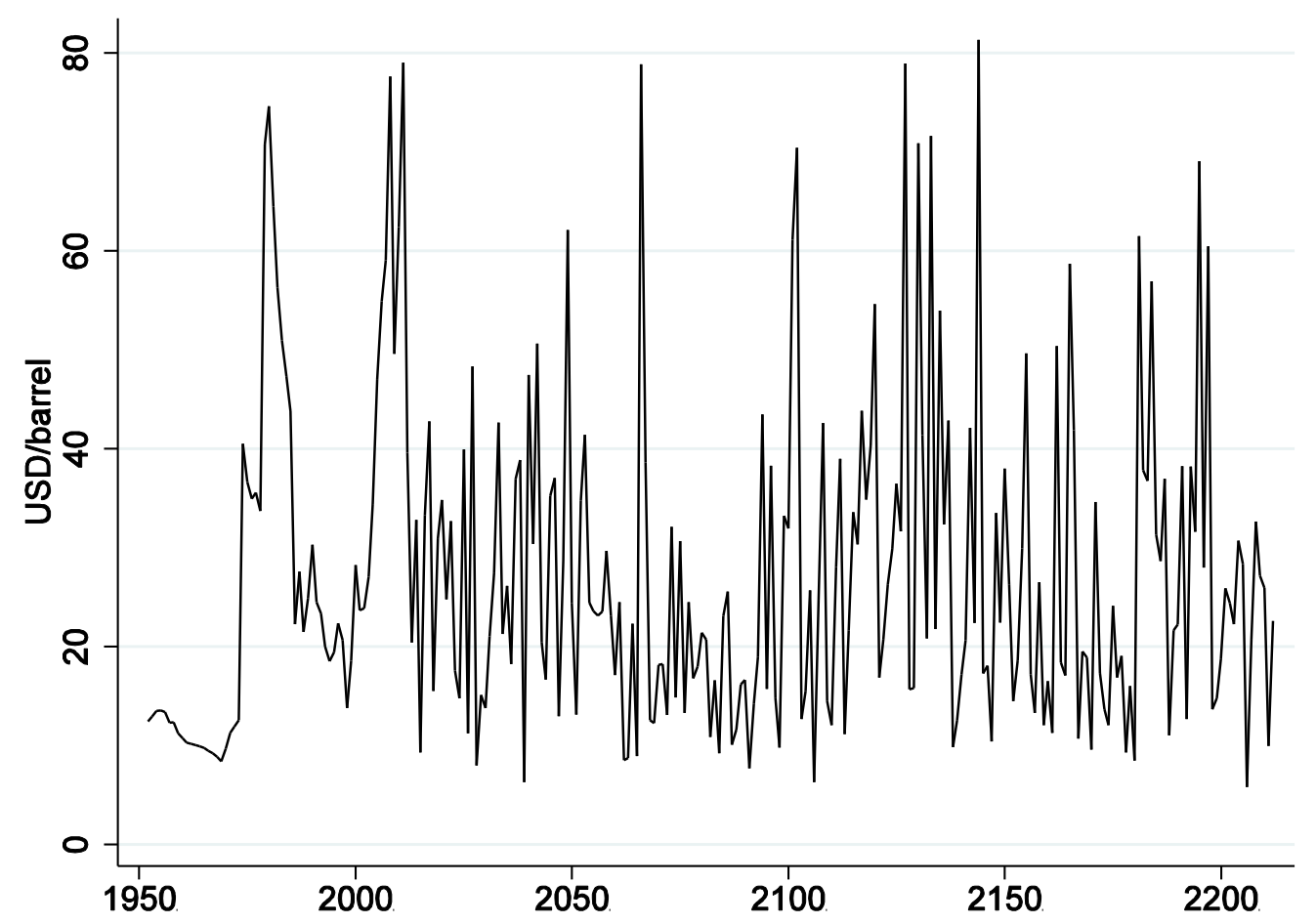

Figure 1. Oil prices real (1952-2011) and simulated (2012-2212) 